\title{
7. 司会者集約
}

土开司・川 末 健 作*

奈良県立医科大学病院

*ホスピネット

\section{1.はじめに}

ここ数年 MR 装置は, 急速に発達し普及してきた. 当 初は, 病変の検出と質的診断を目的として, dicision tree の後半に位置づけされていた。 それが近年になって, MRI の診断学的役割も徐々に変化し,ルーチン検査とし てドックに利用されたり，より微細な存在診断や質的診 断を目的としたもの，そして，形態検查から機能検査へ とMRI の用途も様々になってきた。「見えざるものを見 えるようにする」「わからなかったことを解明する」、「機 能を画像化してより明膫にする」など，いろんな目的で MRI が利用されるようになってきているが, これらのこ とを可能にするためには，よい画像つまり診断価値の高 い画像を提供しなければならない，放射線撮影分科会で は，「よりよい撮影技術を求めて」をテーマにシリーズで ワークショップを開催しているが, MRI における撮像技 術について考えてみると，(1)多種多様な性能の装置のな かで，その装置なりの最高の画像を出すための方法. (2) 誰が撮像しても同じょうに良い画像が撮像できる不変性 な画像撮像テタニック. (3)メーカー間も含めて同じ性能 を持った機種の中での，施設により異なる撮像条件の中 での最適シーケンス.(4)(1)-(3)の目的達成のための各部位 での撮像断面，撮像範囲，スライス厚さ，スキャン角度， パルスシーケンスの決定方法. そしてアーチファクト対 策. などではないかと思える。

今回は, 副題に「ょり早く, より精密に, 上り高品質 に」を揭げ，6名の演者の方にMRI の撮像技術につい て, (1)脳ドックにおける頭部ルーチン検查, (2)頭部造影 検查および高速撮影, (3)腹部領域および MRA, (4)胸部領 域, (5)脊髄領域, (6)経口造影剤およびその他の 6 項目の 領域およびテーマ別に話題提供をお願いした.

\section{2. 各演者の発表概要}

\section{1 脳ドックにおける頭部ルーチン検査}

日本で最も早くから脸ドック検查を手掛けておられる 新さっ哚ろ脳神経外科病院に頭部ルーチン検査扔よび脳
ドックにおける診断能を向上させる手段について話して もらった. IA-DSA から MRA へと移行するにあたって の経緯と MRA における問題点が主であった。

いずれにおいても優秀な画像が提示された。脳ドック のMRA では，脳全体を対象としているが，それぞれの 血管系に応じた最適パルスシーケンスにて撮像すること が必要である：診断に際しては，ひとつの血管に対して 多方向からのステレオ視を基本としている.

MRA での診断能を低下させる要因として, 血流信号 の低下, 信号の不均一, 空間分解能の限界などが考えら れるが，患者の協力を得ることや，撮像シーケンスを選 択すること，新しい技術を導入することにより徐々に回 避されつつある。しかし，常にその信号が生じたプロセ 久を念頭に置いておかなければならないとしている。

\section{2 頭部造影検査および高速撮影}

1990年に慶應大学の樋口先生により開発，実用化され た spin echo 法を改良した RARE (一般呼称 fast spin echo）法を当初より臨床応用されている慶應大学病院 に, 高速撮像法の利点および問題点, 頭部造影検查の臨 床例について話してもらった。

高速撮像法は, 検查時間の短縮を可能にし, heavy $\mathrm{T}_{2}$ 強調画像や高分解能画像を得る方法として大いに有用で ある. $\mathrm{T}_{2}$ 強調画像において，動きや流れの影響を抑える 時には12-16 echo を, SNR を求める際には 8 echo を使 用する. $T_{1}$ 強調画像は TR が短いため 4 echo を用い, dynamic 撮像に威力を発揮する. SAS image や腹部に も有用である。

頭部の造影では, 適宜撮像シーケンスを考慮して使用 することが望まれ，時間分解能を求めた dynamic 撮像, 空閒分解能を求めた小さな FOV と2-3 mm の thin slice が必要な場合もあるとしている。

磁場強度によって高速撮像法で得られた画像に差が生 じるかという質問に対して, 本質的な信号強度の差を埋 めるための処置以外は，別にないとの事であった。

\section{3 腹部領域および MRA}

腹部領域では, 抬動, 呼吸, 血流, 体動など多くのア 
ーチファクトに対する対策が必要である．患者への規則 正しい呼吸の要請, rectangular FOV や presaturation pulse の利用, 呼吸停止の併用, 高速 SE 法の利用などが 考えられる：腹部の dynamic MRI では，より短時間で の広範囲にわたる multislice dynamic study が有用で ある.また，MR-angiographyにおいては，選択的血管 の描出が可能となり，より早く，より明瞭に描出するた めの工夫が追求されている.

Dynamic MRI での撮像断面は, CT との対比で transvers 像か，血管造影と対比するために coronal 像のど ちらを選択するかを司会より非ねた。一般的には，前者 の方が多いであろうが，症例や目的部位により使い分け も必要であると思える。

\section{4 胸 部領 域}

心臓，大血管領域に絞ってアカデミックに話してもら った. SE 法は心筋と血流壁の境界が明瞭に描出でき, 形 態や組織性状の評価に, MR cine は血流信号を描出する ため，心筋壁運動や血流，心機能の評価に使用される.

MR cine の血流信号を適正に獲得するために，スライ ス間隔，スライス厚，flip angleを最適に設定し， rephasing, presaturation の有無を選択しなければなら ない.

また，僧帽弁逆流の定量評価や冠状動脈の描出，心筋 の機能解析，血行動態の観察が可能になってきている.

\section{5 脊髄 領 域}

MRI の特徴を最も発揮しやすい領域のひとつで, SE 法による $\mathrm{T}_{1}$ 強調画像の矢状断像と multi - planar GRASS (MPGR) による $\mathrm{T}_{2}$ 強調画像の矢状断と横断像 が基本となる. Low flip angle MPGR 法による $\mathrm{T}_{2}$ 強調 画像は，椎体が低信号を示すので，骨棘や靱帯の骨化な どの検出が SE 法に比べて容易となる.また，椎間板の髄 核が相対的に高信号になるので，椎間板へルニアの診断 にも有効である。しかし，obliqueになると信昂強度が低 下し，磁場の状態に左右されやすい久点も持っている。

\section{6 経口造影剤および炎の他}

腫瘍親和性の高い経静脈性の Gd-DTPA による造影 像と，消化管と周辺臓器の鑑別を明瞭にするための経口 性のクエン酸鉄アンモニウムによる造影像について，適 证パルスシーケンスの選択と有用性を臨床例を交えて紹 介していただいた。いずれも $T_{1}$ 強調画像にて高信号を 呈する陽性造影剤である，撮像法は，SE 法に加え，呼吸 停止下にて撮像する GRASS 法や脂肪信号の抑制が可 能な Dixon 法が大いに有効的である。

MRI の診断能を向上させるために,いくつもの造影剂
が開発されつつあるが，中でも経口造影剅に造影剤とし て薬事の認可を受けていない製蝺を投与する際には充分 な注意と配慮が必要であり，問題が残ると警鐘された。

\section{3.ディスカッション}

・脳ドックにおけるシステム的な問題点は. 時間的，コ ストの問題，臨床との兼ね合など（神鋼病院：後藤）

長内：ドックの患者は 1 日で 1 人 ( 1 泊 2 日)，1日目の 午後に 1 時間半程で MR 検查を行い, 異常があると翌日 精密検査を行っている.ルーチンの MRA では, $3 \mathrm{~mm}$ 程 度までの動脈瘤を検知することができる。予約待ちは， 2 力月程度である。

・「Fast SE 法で flow のアーチファクトを少なくするに は echo 数を増やした方が良い」の説明を。（東海大学：

室）

朝倉：Echo factor が少ないと, echo 間隔すなわちサン プリング時間が長くなる.Echo factor が増えると, band 幅が広がるがサンプリング時間が短くなる。このことよ り体動や flow の影響は, echo factor が多い方が少ない. 頚髄の MRI では，頭尾方向に位相エンコードを倍マ トリクスとり fast SE法にて non-phase wrap を用いる のが現在での最善の方法である.

- Gd-DTPAの造影でSTIR 法での評価は.（日本医 大：土橋)

小野：目的部位の $T_{1}$ 值が，Gd-DTPA の注入によりど の程度短縮されるかによる，脂肪より短くなると造影効 果が明膫に描出されるが，同程度だと不明瞭になる。

・副題にある「より早く,より精密に，より高品質に」 の相反する項目の中から撮像技術として，何を基準とし て撮像シーケンスを決定していけばよいか.

長内：MRA の場合では，空間分解能を求めることが優 先され，可能な限り薄いスライス厚で撮像する。その中 で，最適シーケンスを選択する。しかし，要因も多い。

撮像断面の決定は，最小のスライス厚を使うためスラ ブの設定を oblique にできない.したがって, target MIP 処理にて各断面を得ている.またその方が分解能も 良い。

・頭部 MRI でのスライス厚やスライス間隔の決定方法 は.

朝倉：目的によってスライス厚は違ってくるが，小さな 病変では最高でも $3 \mathrm{~mm}$ 以下が必要で, 骨のアーチファ クトがなく，コントラスト分解能が高いという特長を生 かさなければならない。

•0.2Tのパーマネントタイプの装置でもスライス厚 5 
$\mathrm{mm}$ で充分な SNR が得られるのか.

普及率の高い $0.2 \mathrm{~T}$ の装置においても，良い画像をだ すための撮像技術（手法）は同じはずである…

- Multi echo法にて得られるプロトン画像と $T_{2}$ 強調 画像, long SE 法にて得られる $\mathrm{T}_{2}$ 強調画像には差があ ると思う。その使い分けと必要性の根拠は.

朝倉：ルーチン検査に扔いてプロトン画像は, 形態学的 に必要である。脳下垂体のように目的部位が限られてい ても, 最低限 $T_{2}$ 強調画像にて全体像を把握しておく. 短 時間撮像可能な fast SE 法の活用となる.

・従来の SE 法と fast SE 法の撮像技術上の違いは.

朝倉：短時間撮像が可能なので, TE を変化させて 2 度 撮像することも可能となった。いままで，TR：2000 msec が基本だったのが現在では，TR：4000 $\mathrm{msec}$ を基 本としている.

・腹部におけるスライス厚の決定は.

: 全肝スキャンすることが基本となってくるので, $\mathrm{T}_{1}$ 強調画像では TRや presaturation の関係でスライス 厚：8-10 mm 厚で15枚程度に限定される。腎臓や脺蔵 では，5-6 mm を使うこともある。

・呼吸のアーチファクトが問題になることが多いが，施 設によりいろいろ工夫をされている場合もある。

シンポジウム $1\ulcorner\mathrm{MRI}$ のアーチファクト」の国立がん センター：半村さんの内容を参照にされたい.

・一般病院で胸部・心臓関係がそれほど普及しないのは。 佐久間：その施設の持つ特殊性がある。心歲の拍動と通 常の血流とは異なった心内腔があり, その周囲に呼吸す る肺が存在する 3 つの動きが交錯する部位である。現在 では, 撮像に時間がかかる. 技術の進歩により時間短縮 や echo planar 法の実用化がなれば普及する可能性があ る。

・脊䯣領域での撮像シーケンスでの注意点について. 特に transvers 像の $\mathrm{T}_{2}$ 強調画像の必要性
臼井：病変の検出能が $\mathrm{T}_{2}$ 強調画像は高い.ヘルニアな どにおいても横断像の $\mathrm{T}_{2}$ 強調画像が診断に重要である. スライス厚は， $3 \mathrm{~mm}$ が望ましいが，SNR の関係で 4 $\mathrm{mm}$ にて撮像している。

・造影剤を用いた場合ままだまだいろんな事をしていか なければならないというょうな撮像技術は必要か.

小野：胸腹部の場合，陽性造影剤である限り，同じよう に高信号を呈する脂肪が存在するので, Dixon 法などを 適宜使っていった方が診断能が向上する．以上

（記名なしの質問は司会から）

\section{4.おわりに}

さまざまな性能を持つ装置をひとつの土俵で比較する ことは, 難しい事である。しかしながら, 各装置に共通 した撮像技術とは，次のような画質因子がかかわってく る. (1)空間解能では, matrix size, pixel size, slice thicknessが，(2)コントラスト分解能は，TR，TE， SNR, flip angle, pulse sequense が, (3) SNR は, FOV, matrix size, slice thickness, averaging, band width, コイル, 磁場強度, TR, TE, flip angle, proton 密度, RF power level, receiver gain，之の他本質的な flow, 血流, 動きやアーチファクトなどが画質を決定する 因子であるといえる。

パネリストの方々には，これらのことを具体的な事例 を基に論じていただいた. 我々が, image quality を追求 していくために，これら相反する多くの画質決定因子を どのような根拠で，どのように設定していくかが技術者 としての撮像技術であると言える.今回のワークショッ プを機に再度基本的事項を確認していただいて MR 画 像の画質向上に生かしていただければ幸いである。

最後に，司会の不手際により終了予定時刻を越えてし まい多くの皆様にご迷惑をかけたことをお詫びいたしま す. 